\title{
Extractivist violence and the COVID-19 conjuncture
}

\author{
Paula Serafini
}

Abstract: This article consists of a theoretical development of the concept of extractivist violence, which is proposed as useful for understanding a conjuncture that is not only characterised by the COVID-19 pandemic, but also by an urgent climate crisis resulting from violent extractivism. Extractivist violence is defined as the combination of different forms of violence exerted upon territories and upon racialised, gendered peoples (their bodies and their cultures) resulting from, and with the purpose of, perpetuating the extractivist model. It is engrained in the zones of extraction, but its logic extends beyond it. Taking Argentina as a starting point of enquiry, the theoretical proposal is followed by discussion of a series of events and phenomena unfolding during the COVID-19 crisis, with the aim of demonstrating how the perspective of extractivist violence is useful for arriving at a deeper and more nuanced understanding of the COVID-19 conjuncture. The article concludes with a consideration of the ethics of care as a counterpart to extractivist violence, and of the ways that care has underpinned a series of responses to COVID-19.

Keywords: Extractivism, violence, climate crisis, COVID-19, care.

Note on the author: Paula Serafini is Lecturer in Creative and Cultural Industries at the Department of Business and Society, Queen Mary University of London. Her work is in the field of cultural politics, and her research interests include extractivism, socioenvironmental movements, cultural production and cultural policy. She is the author of Performance Action: The Politics of Art Activism (Routledge 2018) and co-editor of artWORK: Art, Labour and Activism (Rowman \& Littlefield International 2017) and Arte y Ecología Política (IIGGCLACSO 2020).

https://orcid.org/0000-0002-4278-1832

(C) The author(s) 2021. This is an open access article licensed under a

Creative Commons Attribution-NonCommercial-NoDerivs 4.0 Unported License 


\section{Introduction}

The climate crisis has often been described as a catastrophe, as having irreversible effects, and as an issue affecting the lives of millions across the world, including the lives of generations to come. But mainstream discourse on the climate crisis continues to lack proper contextualisation of its effects, and to highlight certain stages and aspects of human production chains (e.g. emissions) over others (e.g. extraction). As a result, particularly in Global North countries and/or urban centres that remain, for now, detached from the daily realities of the extractive industries, the climate crisis is often still equated to global warming and climate change, without fully considering the long-standing destructive and violent processes of extraction that lie behind. In order to address this persistent lack, I propose that one of the ways in which we can understand the current climate crisis is through the lens of violence, and specifically what I will refer to as extractivist violence.

In Latin America, extractivism goes back to the colonisation of the continent, and is currently embodied in the re-primarisation of economies of the last few decades, in the shape, for instance, of open-pit mining and large scale monocrop agriculture, expressions of the merger of political power and property. Such dynamics result in extreme forms of violence towards human populations and their environments; life is commodified, and security is only guaranteed to those who are proprietors (Segato 2016: 100). In response to this context, scholars and activists in the region have developed important theoretical and empirical work visibilising, analysing and theorising extractivism in Latin America and beyond. Particularly over the last decade and a half, such studies have demonstrated that the industries that are driving climate change, such as the fossil fuel industry-but also large scale farming - are not only responsible for global warming, but are also implicated in a series of violent processes that have devastating effects for local communities, ecosystems, and for the fabric of democracy (e.g. Svampa \& Viale 2014; Merlinsky 2013; Machado Aráoz 2015).

In 2020, the COVID-19 crisis shed light on how environmental destruction and the disruption of ecosystems are exposing humans to new diseases, with the potential of fast-felt devastating effects for all human life. Also, it has brought to the forefront different forms of inequality and injustice (some historically less visible than others) that have led to the disproportionate death of Global South, working class and racialised communities (Sultana 2021). With this conjuncture in mind, this article consists of a theoretical development of the concept of extractivist violence, informed by years of empirical research in Argentina (e.g. Serafini 2018; 2019; 2020) and engagement with anti-extractivist movements, and building on the work of scholars of extractivism and relevant theories on the nature of violence. I develop the concept of extractivist 
violence as a way of encapsulating the different forms of violence linked to the extractivist development paradigm.

Echoing the proposal by Navas et al. (2018), in this task I highlight the need for approaches to socioenvironmental violence that are multidimensional. In addition, I follow from Verónica Gago in her call for a pluralización de las violencias [pluralisation of violences], meaning an approach to the study of violence that takes the form of 'a political cartography that connects the threads that make different forms of violence reveal themselves as interrelated dynamics', so that we can 'denounce that their segmentation looks to lock us into isolated boxes' (Gago 2019: 67, my translation).

This theoretical discussion is followed by a discussion of the COVID-19 crisis in which I look at events and phenomena that unfolded during the pandemic in Argentina and beyond, in order to demonstrate how the perspective of extractivist violence is useful for arriving at a deeper and more nuanced understanding of the COVID-19 conjuncture - and the environmental and social challenges of our time more generally. This is followed by a consideration of the ethics of care as a counterpart to extractivist violence, and a discussion on how care has underpinned a series of responses to COVID-19.

\section{On extractivist violence}

Extractivism is a framework developed by Latin American scholars to describe and understand an economic model based on the intensive and extensive extraction of natural resources, mainly for export. Such model, which dominates the region, is rooted in its violent colonisation and has defined the construction of Latin American states; as a result, extractivism is not a solely economic phenomenon, but rather permeates the spheres of the political, the social and the cultural (Serafini 2020). Recent scholarly work looking beyond the specific context of Latin America and other regions heavily marked by long-established, colonial extractivism, have proposed that extractivism is the material and social manifestation of a logic of extraction, the underpinning logic of contemporary capitalism, which is found in economic activities and labour dynamics beyond the extractive industries and at a global scale (Mezzadra \& Neilson 2017). Under this view, the logic of extraction has become the ultimate form of production of value, embodied most notably in the finance sector (Gago 2019: 106). While focusing mostly on Argentina, a site where extractivism describes a long-standing, colonial logic, in this paper I engage as well with the geographically expansive use of the term, in order to highlight the presence of colonial extractivist dynamics and geographies beyond regions historically conditioned by the 
dominance of extractivism. This will allow me to shed light on connections between colonialism, the climate crisis and contemporary forms of violence such as those experienced as a result of the COVID-19 pandemic, and to demonstrate the usefulness of extractivism as a framework of analysis for social and environmental violence at a time of interconnected global crises.

In extractive societies and in the socioenvironmental conflicts that occur therein, violence can be 'structural, cultural and ecological' (Martinez-Alier \& Roy 2019: 29), and it can manifest in different forms, from pollution to militarisation to epistemicide. In order to understand these different forms of violence and how they are interconnected, I propose the notion of extractivist violence, as the combination of different forms of violence exerted upon territories and upon racialised, gendered peoples (their bodies and their cultures) resulting from, and with the purpose of, perpetuating the extractivist model.

As described earlier, at the basis of extractivist violence in Latin America we find its colonial roots. In colonial states, as argues Fanon, violence becomes present from the first encounter between native and settler (Fanon 1963: 35). The conqueror and the native are constructed as inherently different, where natives are not considered subjects. The colonial power operates as the administrator of violence, and the colonies are ruled in absolute lawlessness as a result of 'the racial denial of any common bond between the conqueror and the native' (Mbembe 2003: 24). Writing on the colonial context, Mbembe builds on Foucault's notions of biopower and biopolitics and proposes the frame of necropolitics. He argues that 'the ultimate expression of sovereignty resides, to a large degree, in the power and the capacity to dictate who may live and who must die' (Mbembe 2003: 11). In this way, Mbembe differentiates between sovereignty as a pursuit of autonomy by the people, and sovereignty as 'the generalized instrumentalization of human existence and the material destruction of human bodies and populations' (ibid: 14). In this context, race functions to 'regulate the distribution of death' (ibid: 17). The colony is therefore a formation of terror that takes place outside of the law, and violence here operates in the name of civilisation (ibid: 24).

In addition to the racial hierarchies that were instrumental to the implementation of slavery and forced extractive labour, colonialism also imposed an extractive geography, which in Latin America facilitated the intensive extraction of metals to expand the fortunes of the 'old continent' and the colonial elites (Machado Aráoz 2015). After the independence struggles, the newly formed sovereign states imposed their own delimitations of space, and these were once again sustained through violence. In this case violence inflicted the rationality of capital accumulation, bureaucracy and the armed forces. Such rationality was imposed by suppressing all other forms of experiencing the territory, specifically those of indigenous peoples (Nouzeilles 1999: 
37). At the same time, this period saw the consolidation of the enclaves, spaces where the territorial sovereignty of the state in relation to foreign entities is suspended or displaced by a foreign normative, and where the aim is 'to guarantee the appropriation and free transfer of capital gain to the capitals that set up therein' (Machado Aráoz 2015: 23, my translation), sustaining and formalising an unequal and violent geography of extraction that reproduces its colonial roots. These different geographical formations and manifestations of violence across time all gave place to dynamics of ecological destruction for accumulation, dynamics that are sustained to this day and exacerbated through the implementation of new technologies that have increased exponentially the magnitude of extractive projects. The sight of an open-pit mine (what many call 'megamining') is so unprecedented that it has inspired the work of many contemporary artists, as a paradigmatic image of ecological violence. ${ }^{1}$

In contemporary forms of extractivism, oil extraction, mining, and other large-scale extraction projects across the region are mostly backed by transnational companies whose interests are protected by the state through increased militarisation. As Da Costa and Da Costa put it, militarisation and corporate plunder are manifestations of different 'coexisting and converging colonialisms' (Da Costa \& Da Costa 2019: 347). The problem that arises, however, is that 'corporate extraction under the threat of militarised state violence refuses the label of colonialism because it is done in the name of "public good" of citizens' development' (Ibid: 348). Indeed, the discourse of development functions as a legitimising actor of extractivist violence: both development and modernisation permeate politicians' rhetoric, on the right and on the left. In my main field of enquiry, which is media and cultural production, we can see how such discourses are mobilised through mainstream media narratives (e.g. celebratory articles framing investments in fracking as Argentina's 'salvation'), and through extractive companies' own acts of cultural sponsorship and greenwashing (Serafini 2020). But as post-development theorists have long argued, both the epistemological and ontological bases of development and the structures of the global development industry are based on colonial visions of the world, which perpetuate the extractive-oriented nature of many Global South economies with the aim of reproducing the current geopolitical dynamics that benefit the accumulation of resources in investing countries and for local elites (Escobar 2005, Gudynas 2011, Ulloa 2015). The development project -itself based on ecologically unsustainable goals in terms of its projections of unlimited growth - has not actually contributed to

${ }^{1}$ Some examples include Diana Dowek's work Bajo la Alumbrera, depicting an open-pit mine in Argentina, which received the 2015 Grand National Painting Award in that country, and the 2018 film installation María Elena by artist Melanie Smith, featuring drone images of an open-pit mine in the Atacama dessert. 
increasing the wellbeing, stability and sovereignty of states -in terms of the management of resources and adequate provision of basic services, as is the case with the much sought 'energy sovereignty' - but to the contrary, has deepened Latin America's position as exporter of nature, and as such, its vulnerability to the fluctuation of commodity prices and its dependency on central economies (Svampa \& Viale 2014). Recognising that coloniality is embedded in these dynamics and processes is crucial because it allows us to identify and 'challenge colonial violence wherever it is erased', be this because it is normalised or because it is read as something else, for instance as nationalism, when extractive development is presented as a national programme (Da Costa \& Da Costa 2019: 349). For these reasons, it is necessary to think about extractivist violence as a complex, multi-layered phenomenon that is bound by structural and political factors, is embedded in cultural specificities, and develops according to local and global histories and politics.

Returning to the issue of the imposition of the extractive regime, we must consider not only the agents of enforcement - the police, the military, and in some regions also private security agents and paramilitary - but also the legal framework that is being defended by state forces, and which consequently endorses the use of physical violence. The role of the law in the management of violence is complex. The state holds the monopoly of violence, and militarism, argues Benjamin, 'is the compulsory universal use of violence as a means to the ends of the state.' (Benjamin 1986: 284) The police applies violence for legal ends, and in addition has 'the authority to decide these ends itself', within certain limits (Benjamin 1986: 286). Benjamin adds that:

the law's interest in a monopoly of violence vis- à-vis individuals is not explained by the intention of preserving legal ends but, rather, by that of preserving the law itself; that violence when not in the hands of the law, threatens it not by the ends that it may pursue but by its mere existence outside the law. (Benjamin 1986: 281)

An important point here is that in the case of conflicts concerning indigenous land rights, what is at stake is not just the state's preservation of the law, but also the preservation of a Western paradigm and its accompanying ideas of development, resource use and modernisation, all of which are threatened by the understanding of territory put forward by indigenous ontologies and practices, which sometimes do not abide for instance by the principles of private property or the imperative of growth (Ulloa 2015). Significant also is that laws and treaties guaranteeing the rights of indigenous communities actually do exist and are recognised by constitutions across Latin America, yet they are too often not upheld (Svampa 2012: 30).

The intensive and extensive extraction of natural resources for profit can generate different forms of violence, from the violation of land rights to impacting people's health, the destruction of ecosystems and even the murder of environmental activists. 
For this reason, it is necessary to create frameworks that contemplate violence on multiple scales and multiple manifestations. For instance, looking at conflicts surrounding oil production, Michael Watts proposes the term petro-violence as

a way of thinking about the intersection of environment and violence: both biological violence, as it were, perpetrated upon the biophysical world, and the social violence, criminality and degeneracy associated with the genesis of petro-wealth and with its ecological destructiveness. (Watts 1999: 1)

Adopting a broader perspective that considers all forms of extractive activity, Eduardo Gudynas (2013) proposes the term extrahección as a way of naming the most violent forms of resource extraction, and the violations of rights that these activities generate. The extractivist form of resource extraction, argues Gudynas, is inherently violent, and it always entails the violation of rights. This can take different forms, and it includes (in)actions on behalf of the state such as the non-implementation of environmental legislation; lack of controls and the neglect of rights of consultation; and actions from corporations such as illegal processes, the use of banned substances and poor conditions for workers. To this we must add, of course, the violence exerted upon those who stand against extractivism, from the judicialisation of opponents to the criminalisation and repression of protesters, which goes in hand with forms of symbolic violence such as delegitimisation campaigns carried out by the media, and, in its most extreme form, the murder of land defenders (Gudynas 2013: 14). Gudynas's framework offers a valuable perspective because it invites us to think about the violence of extraction in gradual terms, to recognise the levels of violence in different types of activity, and to identify the legal, illegal, and alegal mechanisms through which corporations and states infringe rights.

While Gudynas offers a comprehensive and useful tool in the concept of extrahección, in order to understand extractivist violence we must engage more deeply with the gendered, racialised and classed nature of such violence, as well as its basis in coloniality, as developed earlier. Indeed, the United Nations has recently recognised that extractivism is linked to and exacerbates racial inequalities, including violence (United Nations Human Rights Council 2019). In facing this task, it is useful to consider contemporary empirical work on extractivism and violence that highlights such issues. For instance, Gutiérrez Ríos (2014) applies Gudynas's framework to the case of Argentina, particularly the case of the Vaca Muerta shale oil and gas deposit and the advance of fracking. He points to the violent repression that took place on 28 August 2013, when legislators in the province of Neuquén were signing off a deal between the partly state-owned oil company YPF and the transnational company Chevron, and different sectors of society took to the streets to protest the deal. The mobilisation was violently repressed, and the following day three houses belonging to 
members of an indigenous Mapuche community, who were visible opponents to the deal, were burnt down (Gutiérrez Ríos 2014: 50). This case, adds Gutiérrez Ríos, not only saw physical violence against Mapuche people and other protesters, but also saw symbolic violence in the shape of the violation of collective rights. The communities' right to free and informed consent to extractive developments was violated, their juridical condition as indigenous peoples was unacknowledged, and the approval of the deal resulted in the invasion of their territory (Gutierrez Rios 2014: 51). As the extractive frontier expands and conflicts intensify, so does repression of activists and land defenders. Indeed, state and corporate violence have not only been a consequence of the advance of transnational extractive corporations, but also necessary factors for it (Gutierrez Rios 2014: 39), and such forms of violence are often underpinned by colonial racial hierarchies.

Part of the racialised exercise of violence, as argued by philosopher Elsa Dorlin (2019), is the way in which certain subjects are constructed as violent. This dynamic of violence is rooted in coloniality, and is supported through symbolic means. Western societies have an engrained and perverse way of dealing with 'the other' (Herrera Flores 2006: 22), yet there is a 'hegemonic cultivation of colonial unknowing that ensures that our recognition of colonialisms remains limited' (Da Costa \& Da Costa 2019: 354). Returning to Fanon,

[i]t is not enough for the settler to delimit physically, that is to say with the help of the army and the police force, the place of the native. As if to show the totalitarian character of colonial exploitation the settler paints the native as a sort of quintessence of evil. (Fanon 1963: 40)

This construction of the violent subject is visible for instance in the deligitimisation media campaigns against the Mapuche people in both Argentina and Chile, and in the use of anti-terrorist laws to persecute land defenders (Eissa 2018, Trentini \& Pérez 2015).

Another distinctive element in extractivist violence is its gendered dimension. In her study of oil extraction in Nigeria, Turcotte proposes that 'understanding petro-politics - or, for that matter, any politics - means recognizing that gender violence is part of a larger political economy of violence that creates the conditions fostering and facilitating petro-politics in the first place' (Turcotte 2011: 201). What this means for extractive violence, is that gender violence takes place within extractive economies (e.g. physical, symbolic, economic), but also, transnational structures within a colonial, patriarchal system enable different forms of extractive violence to occur, including but not limited to its gendered manifestations.

Important to consider when we speak of extractivist violence is also the different temporalities that this can take. We are used to thinking of violence as spectacular 
acts, tied to specific moments and events. But several consequences of extractivism, from the many effects of pollution at the local level to climate change, unfold over long periods of time, sometimes in ways that are not clearly visible. This is what Rob Nixon has termed slow violence (2011), a form of violence whose danger lies in the fact that it is often not perceived as violence at all.

In addition to time, there are spatial dynamics that condition extraction, both at the local and global scale. For instance, while most extraction takes place outside of cities, in recent years scholars in Argentina have begun to employ the framework of extractivism to describe urban dynamics, and to connect different forms of violence, displacement and dispossession in urban settings to the dynamics of rural environments and extractive sites. Urban extractivism thus emerges as a framework that connects the logics of extraction, destruction and dispossession reproduced by the extractive industries with similar and interrelated processes occurring in urban areas (Vásquez Duplat 2017). The concept of 'urban extractivism seeks to provide a new explanatory matrix that can address the problems and inequalities in cities, not as isolated elements, but as the result of a specific and planned development model' (Centro de Estudios y Acción por la Igualdad \& Fundación Rosa Luxemburgo 2017: 11, my translation). Examples of this include pollution and sanitation problems in urban settings, the demise of green spaces, the privatisation of public space and the displacement of working class communities as a result of gentrification processes.

Finally, a situated and nuanced understanding of extractivist violence in any one context requires considering the historical precedents of the locality, and how previous experiences of violence have shaped collective understandings and imaginaries. In my field research I found that in order to denounce violence, struggles against extractivism in Argentina often use terms like 'genocide', 'ecocide' and 'terricide'. In this context, the term genocide echoes both the mass murder of indigenous populations through colonialism, as well as the persecution and killing of 30,000 people during the last civic-military dictatorship (1976-1983). As such, it is a term that is an important part of the framework of the local human rights movement (Feierstein 2014), a movement that has supported various social struggles throughout the decades, and that is now also supporting mobilisations against the devastating effects of extractivism. The term 'ecocide' in turn has been used for denouncing extractivist violence from an eco-centric perspective, and finally, the term 'terricide', notably put forward by the collective Movimiento de Mujeres Indígenas por el Buen Vivir [Movement of Indigenous Women for Good Living], highlights the different forms of violence experienced by indigenous people and their territories, from pollution to racism and epistemicide. Such terms offer increasingly holistic conceptions of violence, which allow us to understand extractivism from a comprehensive, necropolitical perspective. As a result of the COVID-19 pandemic, as I will propose, necropolitics 
have acquired new dimensions, as the links between life, death and environmental destruction are exposed in new ways.

\section{The COVID-19 conjuncture}

Conjunctural analysis, an approach famously developed by Stuart Hall building on Gramsci, is a way of seeking to understand the complex and multi-layered nature of a particular moment, made up of specific political, social and cultural forces. The conjuncture condenses 'forces, tendencies, forms of power, and relations of domination and subordination' (Clarke 2014: 115). Conjunctural analysis thus avoids 'seeing history as a series of repeats', and duels on contradictions and the different tempos of overlapping phenomena (Hall 1979: 14). Doing conjunctural analysis involves considering the multiple causes in a crisis, as well as the multiple possible outcomes. It stems from a 'commitment to understanding how social relations and underlying historical processes c[o]me together in particular contexts' (Featherstone 2017: 38), and it is a political task, as argued by Hall, because it aims to 'reveal the possibilities and resources for progressive action' (Ibid). The concept of conjuncture can be useful for attempting to understand the present moment, a moment characterised by multiple, overlapping crises and in which the COVID-19 pandemic and the unknowns it carries have led to unexpected and sometimes contradictory acting on behalf of governments. Rather than conducting an in-depth conjunctural analysis, in the following pages I focus on demonstrating how the notion of extractivist violence can contribute to the understanding of the COVID-19 conjuncture. I do this by considering a number of phenomena, dynamics and events, focusing first on Argentina as a site of enquiry and then looking beyond.

In the first place, the COVID-19 pandemic can be understood in terms of extractivist violence because it is the result of a changing relationship between humans and their environment and humans and other living beings, relationships that are increasingly based on violence and destruction. This includes deforestation, extraction, carbon-fuelled climate change, the trafficking of animals, and factory breeding of animals for human consumption. As a result, the risk of inter-species disease transmission has increased, and as the COVID-19 pandemic has taught us, humanity is not prepared to contain such new forms of ailments, which are propagated with greater ease in an era of global mobility (Merlinsky 2020). COVID-19 can thus be understood as the result of a relationship to other beings and ecosystems that is based on a logic of extraction. 
COVID-19 has also brought to light certain urban dynamics of structural violence and inequality, dynamics that are connected, in different ways, to the roots of extractivism. Consider the following four examples.

In cities where there are shantytowns and informal settlements, as is the case of Buenos Aires, crowded housing has not only made lockdown more difficult for some people, but has also prevented the possibility of socially distancing, placing some at a higher risk of infection. Such living conditions are directly connected, in this context, to the migration from rural areas to urban centres resulting from the enclosure of land and the expansion of monocrop, large scale, GMO agriculture, one of the key sectors of the extractivist models of countries like Argentina, Brazil and Paraguay (Nodal 2013).

In cities across the world, the lack of access to green space has become an increasingly urgent matter in terms of wellbeing, and one that has been found to be classed and racialised (Boyce Kay 2020). The restrictions on movement imposed as a result of the pandemic highlighted dynamics of enclosure of green (and) public space that are common to many cities, and that are often related to the financialisation of housing. In the Latin American context, this phenomenon is understood as a form of urban extractivism, and considered in parallel to the financialisation of agriculture and the processes of enclosure and displacement it gives place to in rural areas (Vásquez Duplat 2017).

Also in Buenos Aires, access to running water has gone from a longstanding yet neglected issue affecting the poor and marginalised in urban centres and their peripheries, to a recognised matter of public health, as neighbourhoods with inexistent or inconsistent access to running water have become hot spots for the virus, which then circulated elsewhere. It is worth noting that the lack of water in popular neighbourhoods and settlements is not coincidental, as the planning and expansion of service infrastructure deliberately avoids such locations and prioritises the provision to wealthier areas (Merlinsky \& Tobías 2020). This form of environmental and social inequality can thus be understood as a form of violence within the frame of urban extractivism. Not only this, but COVID-19 has also meant a change in the temporality of extractivist violence: while issues like frequent cuts to running water are often normalised despite their detrimental effects, the pandemic situation has accelerated and exacerbated the effects of such forms of violence and neglect on behalf of states.

And finally, in the UK, air pollution has been found to have an effect on how people respond to COVID-19, and data shows that black and other ethnic minority groups are being disproportionally affected by it (Soltan 2020). This racialised and classed differential exposure to pollution, which is in fact a longstanding matter 
(Olufemi 2020, 126), demonstrates the imposition of colonial, extractivist geographies and necropolitics in different contexts (from former colonies to the belly of empire), and how environmental factors and consequently health are conditioned according to those geographies. ${ }^{2}$

Another way in which the perspective of extractivist violence contributes to our understanding of the conjuncture is through the specific way in which it activates the concept of necropolitics. Who lives and who dies during this pandemic is linked to political decisions and the logics and ideologies that underpin them, and to the economic and infrastructural capabilities of different countries, which are, for many countries in the Global South, conditioned by histories of extractive colonialism. It is also linked, as expected, to race and class, as pre-existent patterns of inequality were only exacerbated by the crisis context. Building on Foucault as does Mbembe, Agamben (1998) recovers the notion of bare life to describe the merely biological aspect of life, which is different to the good life afforded to citizens. This notion, he proposes, underpins how biopower operates, and as a result, which lives become justifiably disposable. In general terms the disproportionate death of the poor and of racialised minorities, which often intersect, has been linked - in different degrees according to context - to the kinds of employment people are able to access (often low-paid 'essential' or 'frontline' jobs which mean greater exposure) and their living conditions (e.g. access to water, possibility of distancing, and a pollution-free environment). In places like Brazil, furthermore, we have seen extreme examples of a necropolitics that rests on a neo-fascist and neoliberal logic, and reproduces a violence of inaction. In Brazil, where the recent prison population count is 773,151 , making it the third largest in the world, multiple news sources reported that inmates were left to die after spikes of COVID-19 in prisons. The prison population in Brazil is majority Black and poor, as are those most affected by COVID-19 across the country. Given president Bolsonaro's history of racist remarks and his disdain for the wellbeing and basic rights of imprisoned people, his government's inaction has been interpreted not as a matter of unpreparedness, but as a deliberate disregard for those lives (Arantes 2020). Here, as well that the Amazon rainforest had recently been put up for sale to the highest bidder, with the argument that preserving the environments of indigenous peoples is an obstacle for progress (Phillips 2019). In Brazil, a country long-affected by extractivism but which is in addition currently under an administration that is openly neoliberal, racist, homophobic and violent, the commodification of ecosystems and territories and the lack of safeguarding of minoritised groups in the face

${ }^{2}$ This phenomenon was termed environmental racism by grassroots activists in the US in the 1980s, when different communities began to organise around the awareness of a classed and above all, racialised distribution of environmental hazards (Colsa Perez 2015). 
of COVID-19 are part of one same accelerated and intensified logic of extraction that sees certain lives and whole ecosystems as disposable unless economically profitable, and that is executed through, and gives way to, multiple forms of violence. Indeed, as Gudynas has observed, necropolitics has become functional to the preservation of 'an economy that rests on the massive appropriation of natural resources for export' (Gudynas 2021, my translation).

As a final example, I look at a recent trade-related development in Argentina, in order to shed light on both the transnational dimension of extractivist violence, and to return to the matter of the direct link between extractivism and the generation of conditions that can give place to future pandemics. In March 2020, when COVID-19 hit the country, Argentina was already experiencing a deep economic crisis, and presented astonishing levels of foreign debt. The pandemic therefore found Argentina at a time of very limited funds, and in the midst of the restructuring of debt payment plans with the International Monetary Fund. As cases of COVID-19 continued to rise, in July it was announced that the government was negotiating an agreement with China for the production of pork meat, an agreement that foresaw investments of US\$ 3,800 million over four years, and which would involve Argentina breeding an extra 900,000 tons of pork meat during that period, effectively doubling its current production in a short period of time (Télam 2020). The deal entailed outsourcing China's local production to Argentina, and was framed by the Argentine government and by the local agribusiness sector as a hugely beneficial deal that would strengthen the sector by increasing value added; at the moment Argentina exports crops to China where they feed their own pigs for meat production. However, what was left out of the announcement was the environmental consequences of such a rapid and exponential increase in cattle breeding. While feeding crops are already being produced, at this scale the breeding of pigs would require over 500,000 extra hectares for soya and corn for feeding (Napoli \& Di Paola 2020). To this we must add, of course, how the production of meat in itself is a known driver of climate change, and the ethical implications of mass, factory breeding. And second, there is the reason why China decided to withdraw from the mass breeding of pigs in the first place. In 2019 Chinese breeders had to put down 1 million pigs due to an outbreak of African swine fever. The proposed trade deal between Argentina and China can therefore be seen as a transfer of environmental risk, a form of extractivist necropolitics in which the possibility of uncontrollable disease, death -and sudden economic loss-is transferred to a country that is dependent on the exploitation of nature in order to generate revenue. Argentina's economic dependency means that in the eyes of the global market (and of its own political and economic elites) it is a risk worth taking. In other words, the economic dependency underpinning an extractivist development model makes the lives and livelihoods of Argentinians less valuable. In this case, the connection between 
extractivism and public health is a key factor for considering the reasons behind China's decision to outsource production, as well as for evaluating the possible consequences for Argentina. The concept of an extractivist necropolitics is useful here for framing the relationships of power between countries, and the risks that Argentinians are expected to take under an uneven, extractivist global economy.

The announcement of the trade deal generated a lively public debate which included an open letter in July 2020, signed by several Argentine intellectuals and public figures opposing the deal, centring their argument on the potential dangers for public health of such a large-scale animal breeding project, among other concerns related to the forms of extractive violence discussed earlier. ${ }^{3}$ In this way, the environmental dimension gained a central role in a public debate on a trade deal in an unprecedented manner, and this dimension was also clearly linked to matters of public health, opening in this way the door towards a new way of considering and debating economic decisions in the public and political spheres.

\section{Care at the conjuncture}

In the face of different manifestations of extractivist violence, frontline communities, grassroots groups and activist networks have for long been leading the resistance to extractivism across Latin America, advocating for ways of living that are more socially just and in balance with our ecosystems. Resistance to extractivist violence has pursued a plethora of avenues, from campaigning to legal challenges, protests, the creation of autonomous spaces, networks and economies, and the production of artistic work that envisions and enacts non-extractive ways of being. Resistance manifests as spectacular acts, but also in the form of daily acts of care.

Within the opposition and alternatives to extractivism, there are a range of coexisting perspectives, paradigms and practices, such as ecofeminism (Korol 2016), Sumak Kawsay and other indigenous world(view)s and social projects (Cuestas-Caza 2018), agroecology and the movement for food sovereignty (Goulet et al. 2014), and autonomous organising (Zibechi 2012). Two common elements among these different visions and practices are that they place care at the centre, and that they are based, whether implicitly or explicitly, on the notion of interdependence. By interdependence, I refer to the fact that the survival and thriving of individuals is dependent on others, and in turn, the survival of human communities is connected to and dependent

${ }^{3}$ See 'No queremos transformarnos en una factoría de cerdos para China, ni en una fábrica de nuevas pandemias' https://argentina.indymedia.org/2020/07/24/no-queremos-transformarnos-en-una-factoriade-cerdos-para-china-ni-en-una-fabrica-de-nuevas-pandemias/ 
on the survival of wider ecosystems. Care is thus understood not only as a humanoriented task or form of labour, but rather in an expanded way that includes care for human and nonhuman ecosystems. This perspective is summed up in the words of Sergio, a member of the assembly against open-pit mining in the Argentine town of Andalgalá: 'the love of the land, of water, of ourselves, of each other. The struggle is for love. ${ }^{4}$

The notions of care and interdependence have been developed in the work of Latin American indigenous women and ecofeminists (e.g. Gargallo Celentani 2014; LaDanta LasCanta 2017), in the practices of Latin American autonomous and territorial movements in the 1990s and 2000s (Sitrin 2010) and also in the writing of Global North feminist thinkers studying the ethics of care (e.g. Tronto 1995; Puig de la Bellacasa 2017). These ideas are therefore not new, but as a counterpart to the forms of extractivist violence that led to and were exacerbated by COVID-19, the pandemic gave place to a widespread realisation of how much we depend on other humans and on other elements of our ecosystem for our personal and communal wellbeing and survival (Fine \& Tronto 2020, 2). This broadened realisation has not only had consequences in terms of how we understand the world we live in, but has also guided immediate responses to the virus at the personal and community levels. These responses can be understood as manifestations of an ethic of care (The Care Collective 2020).

For instance, at the local and grassroots level, we have seen the surge of mutual aid responses around the world, often fostered by feminist organisations (Sultana 2021: 451 ) in ways that prefigure societies based on closer social bonds and a more present understanding of interdependence (Sitrin \& Colectiva Sembrar 2020), where care is seen as an element of the social commons (Hardt \& Negri 2020: 82). The delivery of food and medicine to the elderly and the vulnerable, the collection and distribution of groceries for those who were suddenly found without an income, and the organised provision of emotional support to those affected by isolation are just some of the many expressions of care that looked to address the most immediate problems caused by the COVID-19 crisis at a community level. Important to note is that in some parts of the world, as is in the UK, where I am currently writing from, we might argue that many of the problems that emerged during the COVID-19 pandemic are related to pre-pandemic forms of living, structures and attitudes, which include high levels of isolation, insufficient small-scale, local food production for subsistence, and an underlying and now hyper-enhanced crisis of the care sector (The Care Collective 2020),

\footnotetext{
${ }^{4}$ Personal interview with Sergio, 29 March 2018.
} 
issues resulting from the composition of the global economy as well as the local embeddedness of neoliberalism.

With regards to activist and intellectual responses, May 2020 saw the publication of a collaborative document titled Hacia un Gran Pacto Ecosocial y Económico en Argentina [Towards a great ecosocial and economic pact in Argentina], ${ }^{5}$ and soon after the Pacto Ecosocial del Sur [Ecosocial pact of the South]. ${ }^{6}$ These proposals are comparable to other recent initiatives such as the Green New Deal in the United States, but emerge from the Latin American context, and respond not only to the crises of inequality and environmental destruction, but also to the challenges and opportunities posed by the COVID-19 pandemic. The document for a great ecosocial and economic pact in Argentina states that 'what awaits is not only other pandemics, but the multiplication of diseases linked to ecological degradation and the worsening of the climate crisis', ${ }^{7}$ in this way pointing to the links between the violence of extractivism on territories and the emergence of viruses like COVID-19. At the same time, these pacts view the current conjuncture as an opportunity to rethink the organisation of society, proposing new models of production and governance based on notions of interdependence and care that 'connect redistributive, gender, ethnic and environmental justice.8

Beyond the work of grassroots groups and activist and intellectual networks, under the current system it is of course the responsibility of governments and state institutions to care for the population at a time of crisis. In reference to this, Fine and Tronto propose that ' $[\mathrm{t}]$ he strengths of successful responses to the pandemic and the failings of other strategies can all be traced back to how care, understood in this broad way, has been enabled, supported, managed and matched to needs' (Fine \& Tronto 2020: 2) - without minimising, I would add, the financial possibilities of different states. It is important, therefore, that we consider care as a political act, which not only responds to the effects of the virus on the human body, but to the acts of extractivist violence that led us here, and to the structural inequalities that define the necropolitics of the conjuncture.

In Argentina, the context of the pandemic saw advances in policy on the economy of care, a sector that experienced a rapid, increased visibility during the period of isolation, and that as a result brought to the forefront long-standing yet invisibilised debates on the nature of care labour. In July 2020, the Inter-ministerial Table of Politics of Care, coordinated by the National Ministry of Women, Gender and

\footnotetext{
${ }^{5}$ See https://pactoecosocialyeconomico.blogspot.com/2020/05/

${ }^{6}$ See https://pactoecosocialdelsur.com/

${ }^{7}$ See https://pactoecosocialyeconomico.blogspot.com/2020/05/, my translation.

${ }^{8}$ See https://pactoecosocialdelsur.com/\#1592362596334-8e141cec-613c
} 
Diversity, presented its first document, titled 'Let's Talk about Care'. The report defines the economy of care and highlights the negative impact that the unequal distribution and organisation of care has on the struggle for gender equity (Risso 2020). The fact that at the same time the government was negotiating the trade deal for pig farming with China, however, points to the need for an expanded and transversal understanding of care that includes caring for communities and ecosystems through actions that are sustainable, non-destructive, and based on the notion of interdependence.

Returning to the matter of interdependence, we can say that COVID-19 has brought to the forefront certain ontological questions concerning our understanding of nature, of humanity, and consequently, the location of agency in care. Not long before the pandemic, Puig de la Bellacasa had asked:

What does caring mean when we go about thinking and living interdependently with beings other than human, in 'more than human' worlds? Can we think of care as an obligation that traverses the nature/culture bifurcation without simply reinstating the binaries and moralism of anthropocentric ethics? How can engaging with care help us to think of ethical 'obligations' in human-decentered cosmologies? (Puig de la Bellacasa 2017: 13)

In other words, what Puig de la Bellacasa, among others, had already proposed, was that we desist to understand care as an exclusively human activity, and instead acknowledge that we are immersed in relations of care with other non-human actors. Such ontological questions bring to mind Andean views on the agency of different elements of ecosystems, what Marisol de la Cadena has termed 'Earth Beings', and include entities such as mountains (de la Cadena 2015). Perhaps the unexpected shift that COVID-19 has generated in certain public debates and understandings of our place in the world -albeit if not generalised-is also an opportunity to go deeper into these questions and to push the public debate further, so that it is not only about recognising that the destruction of ecosystems has led to our current situation, but also, that hegemonic conceptions of nature and of humans' place in the world is why and how this happened in the first place.

\section{Conclusion}

The extractive frontier is expanding, and as it expands, we can witness an increase in territorial conflicts, in environmental degradation, and in violence exerted against territories, against women, against indigenous peoples and other racialised subjects, against those who are deemed 'unproductive', and against those who dare say 'no' to 
the extractivist model. In the hegemonic narrative, extraction is the road to development and modernisation, and any opposition to it must be repressed, be that through physical violence, or through symbolic violence in the form deligitimisation and the refusal of rights. This violence is part of the colonial condition that characterises many Latin American and other Global South states, one that is also defined by engrained racism and an understanding of territory as land to be conquered and utilised as economic resource. But the colonial extractivist logic, as I have argued, is not confined to the colonised territories, and it is easy to identify dynamics of colonial, extractive violence beyond those contours.

In this article, I proposed the perspective of extractive violence as a lens for further understanding the causes of the COVID-19 crisis, the way it unfolded, and some of the specific violent dynamics it exposed, reproduced, and exacerbated. Specifically, I argued that extractivist violence has its roots in colonialism, that it is inflicted on humans, non-human beings and ecosystems, that it is structural and manifests as both physical and symbolic, and that it is inherently gendered and racialised. Further, I demonstrated how the notion of extractivist violence can help us understand the connections between environmental violence and health and the kinds of inequalities that have left certain groups more exposed to COVID-19. I also showed how the notion of extractivist violence can contribute to elaborating a necropolitical perspective that is intersectional and ecological. In other words, the perspective of extractivist violence highlights the violent origins of the pandemic, and the ways in which this violence is intrinsic to longstanding social and economic models based on a logic of extraction.

In addition, I examined the notion of care as a counterpart, and considered how care underpinned immediate responses to the COVID-19 crisis. I argued that in some cases responses can be understood as adhering to an ethics of care based on a heightened awareness of interdependence, and that this awareness is in line with the kind of perspectives and responses elaborated by frontline communities and scholars in the face of extractivist violence.

Since the early stages of the pandemic, we have seen multiple attempts to understand the origins, dynamics and consequences of COVID-19. During the time since COVID-19 first appeared, I found myself writing a number of pieces on the matter, each time adopting a slightly different perspective. Why the need to keep tackling the same subject? In this case, why adopting the lens of extractivist violence to understand the COVID-19 conjuncture? The answer I offer, is that it is about putting forward perspectives that allow us to better identify certain connections between processes, even if some of those processes have been discussed before. It is about the power of the story, and about iteration with difference. Donna Haraway eloquently expresses this idea in the conclusion to a chapter that relates the use of oestrogen with 
medical purposes for animals and humans with multispecies responsibility and environmental matters:

It is no longer news that corporations, farms, clinics, labs, homes, sciences, technologies, and multispecies lives are entangled in multiscalar, multitemporal, multimaterial worlding; but the details matter. The details link actual beings to actual responseabilities. Each time a story helps me remember what I thought I knew, or introduces me to new knowledge, a muscle critical for caring about flourishing gets some aerobic exercise. Such exercise enhances collective thinking and movement too. (Haraway 2016: 115-116)

I hope that the reflections and analytical tools offered here contribute to strengthening important conceptual links between extractivism and matters of social justice and public health, and to the understanding of the unprecedented crisis we are currently facing. In the words of Stuart Hall: 'Why analyse the current conjuncture? Because I want to know what to do about it!' (Hall 2004).

\section{Acknowledgements}

I am grateful to the British Academy and the Leverhulme Trust for supporting my first research project on extractivism through a Small Research Grant (2017-2019), the findings from which I draw on in this article.

\section{References}

Agamben, G. (1998), Homo Sacer: Sovereign Power and Bare Life, trans. D. Heller-Roazen (Redwood City, Stanford University Press).

Arantes, M. (2020), 'COVID-19 in Brazilian prisons: Pandemic or a necropolitical project?', Democary Now, 7 July. https://www.opendemocracy.net/en/democraciaabierta/COVID-19-brazilian-prisonpandemic-or-necropolitics/

Boyce Kay, J. (2020), "'Stay the fuck at home!”: feminism, family and the private home in a time of coronavirus', Feminist Media Studies. https://doi.org/10.1080/14680777.2020.1765293

Benjamin, W. (1986 edn) Critique of Violence, in Reflections: Essays, Aphorisms, Autobiographical Writings, trans. E. Jephcott (New York, Schocken Books).

de la Cadena, M. (2015), Earth Beings: Ecologies of Practice across Andean Worlds (Durham NC, Duke University Press). https://doi.org/10.2307/j.ctv11smtkx

Centro de Estudios y Acción por la Igualdad \& Fundación Rosa Luxemburgo (2017), 'Presentación', in A.M. Vásquez Duplat (ed.), Extractivismo urbano. Debates para una construcción colectiva de las ciudades (Buenos Aires, Fundación Rosa Luxemburgo; Ceapi; El Colectivo), 9-11.

Clarke, J. (2014), 'Conjunctures, crises, and cultures valuing Stuart Hall', Focaal, 70: 113-22. https://doi.org/10.3167/fcl.2014.700109

Cuestas-Caza, J. (2018), 'Sumak Kawsay is not Buen Vivir', Alternaturas, http://www.alternautas.net/blog/2018/3/2/sumak-kawsay-is-not-buen-vivir 
Da Costa, D. \& Da Costa, A.E. (2019), 'Introduction: Cultural Production under multiple colonialisms', Cultural Studies, 33(3): 343-69. https://doi.org/10.1080/09502386.2019.1590436

Escobar, A. (2005), 'El "postdesarrollo" como concepto y práctica social', in D. Mato (ed.), Políticas de economía, ambiente y sociedad en tiempos de globalización (Caracas, Facultad de Ciencias Económicas y Sociales, Universidad Central de Venezuela), 17-31.

Eissa, S.G. (2018), 'Construyendo al enemigo: la securitización del reclamo mapuche (agosto-diciembre de 2017)', Perspectivas Revista de Ciencias Sociales, 3(5): 35-61. https://doi.org/10.35305/prcs.v0i5.214

Fanon, F. (1991 [1963]), The Wretched of the Earth (New York, Grove Weidenfeld).

Featherstone, D. (2017), 'Stuart Hall and our current conjuncture', IPPR Progressive Review, 24(1): 36-44. https://doi.org/10.1111/newe.12035

Feierstein, D. (2014), Genocide as Social Practice: Reorganizing Society under the Nazis and Argentina's Military Juntas (New Brunswick, Rutgers University Press). https://doi.org/10.26530/OAPEN_625248

Fine, M. and Tronto, J. (2020), 'Care goes viral: care theory and research confront the global COVID-19 pandemic', International Journal of Care and Caring, 4(3): 301-9. https://doi.org/10.1332/239788220X15924188322978

Gago, V. (2019), La potencia feminista. O el deseo de cambiarlo todo (Madrid, Traficantes de Sueños).

Gargallo Celentani, F. (2014), Feminismos desde Abya Yala. Ideas y proposiciones de las mujeres de 607 pueblos en nuestra América (Mexico DF, Editorial Corte y Confección).

Goulet, F., Magda, D., Girard, N. \& Hernández, V. (2014), 'La agroecología y la cuestión de la convivencia de modelos de desarrollo agrícola', in V. Hernández, F. Goulet, D. Magda \& N. Girard (eds), La agroecología en Argentina y en Francia: miradas cruzadas (Buenos Aires, INTA), 141-7.

Gudynas, E. (2011), 'Más allá del nuevo extractivismo: Transiciones sostenibles y alternativas al desarrollo', in F. Wanderley (ed.), El desarrollo en cuestión. Reflexiones desde América Latina (La Paz, Oxfam \& CIDES UMSA), 279-410.

Gudynas, E. (2013), 'Extracciones, Extractivismo y Extrahecciones. Un marco conceptual sobre la apropiación de recursos naturales', Observatorio del Desarrollo, 18: 1-18.

Gudynas, E. (2021), 'Necropolítica: la política de la muerte en tiempos de pandemia', SERVINDI, 16 April. http://www.servindi.org/actualidad-opinion/16/04/2021/necropolitica-la-politica-de-lamuerte-en-tiempos-de-pandemia

Gutierrez Rios, F. (2014), 'Acuerdo YPF-Chevron: Violencia física y simbólica en el contexto extractivista petrolero en la Argentina', Anuari del Conflicte Social, 4: 37-57.

Hall, S. (1979), 'The Great Moving Right Show', Marxism Today, January: 14-20.

Hall, S. (2004), 'Through the prism of an intellectual life', paper presented at the Caribbean Reasonings Conference- Culture, Politics, Race and Diaspora: The Thought of Stuart Hall, University of the West Indies. Available at: https://www.youtube.com/watch?v=-soRbC6BbJ8

Haraway, D. (2016), Staying with the Trouble. Making Kin in the Chthulucene (Durham NC, Duke University Press). https://doi.org/10.2307/j.ctv11cw25q

Hardt, M. \& Negri, A. (2020), 'Empire twenty years on', New Left Review, 120: 67-92.

Herrera Flores, J. (2006), 'Colonialismo y violencia. Bases para una reflexion pos-colonial desde los derechos humanos', Revista Crítica de Ciências Sociais, 75: 21-40. https://doi.org/10.4000/rccs.897

Korol, C. (2016), Somos tierra, semilla, rebeldia: Mujeres, tierra y territorios en América Latina (GRAIN, Acción por la Biodiversidad \& América Libre).

LaDanta LasCanta (2017), 'De la teología al antiextractivismo: ecofeminismos en Abya Yala', Ecología Política, 54: 35-41.

Martinez-Alier, J. \& Roy, B. (2019), 'Editorial: Some Insights on the Role of Violence. Ecology, Economy and Society', INSEE Journal, 2(1): 27-30. https://doi.org/10.37773/ees.v2i1.53 
Mbembe, A. (2003), 'Necropolitics', Public Culture, 15(1): 11-40. https://doi.org/10.1215/08992363-15-1-11

Merlinsky, G. (2013), Politica, derechos y justicia ambiental. El Conflicto del Riachuelo (Buenos Aires: Fondo de Cultura Económica).

Merlinsky, G. (2020) 'La pandemia como crisis ecopolítica. Desafíos de investigación', CLACSO, https://www.clacso.org/en/la-pandemia-como-crisis-ecopolitica-desafios-de-investigacion/

Merlinsky, G. \& Tobías, M. (2020), 'Pandemia, desigualdades ambientales y acceso al agua en el Área Metropolitana de Buenos Aires', Revista Sociedad, 41: 46-8.

Napoli, A. \& Di Paola, M.M. (2020), 'Cerdos para China: más preguntas que certezas', Infobae, https://www.infobae.com/opinion/2020/08/14/cerdos-para-china-mas-preguntas-que-certezas/

Navas, G., Mingoría, S. \& Aguilar-Gonzáles, B. (2018), 'Violence in environmental conflicts: the need for a multidimensional approach', Sustainability Science, 13: 649-60. https://doi.org/10.1007/s11625-018-0551-8

Nixon, R. (2011), Slow Violence and the Environmentalism of the Poor (Cambridge MA, Harvard University Press). https://doi.org/10.4159/harvard.9780674061194

Nodal (2013), Entre Argentina, Bolivia, Brasil, Paraguay y Uruguay se sembraron 50 millones de hectáreas con soja transgénica en 2012. https://www.nodal.am/2013/09/argentina-bolivia-brasil-paraguayy-uruguay-sembraron-50-millones-de-hectareas-con-soja-transgenica-en-2012/

Nouzeilles, G. (1999), 'Patagonia as borderland: Nature, culture, and the idea of the state', Journal of Latin American Cultural Studies, 8(1): 35-48. https://doi.org/10.1080/13569329909361947

Olufemi, L. (2020), Feminism, Interrupted: Disrupting Power (London, Pluto). https://doi.org/10.2307/j.ctvxrpzvs

Phillips, D. (2019) 'Bolsonaro declares 'the Amazon is ours' and calls deforestation data 'lies", The Guardian, 19 July. https://www.theguardian.com/world/2019/jul/19/jair-bolsonaro-brazil-amazonrainforest-deforestation

Puig de la Bellacasa, M. (2017), Matters of care: speculative ethics in more than human worlds (Posthumanities, Minnesota, University of Minnesota Press).

Risso, N. (2020), 'Informe del Ministerio de Mujeres, Género y Diversidad. Valorar la economía del cuidado', Página12, 27 July.

https://www.pagina12.com.ar/281031-valorar-la-economia-del-cuidado

Segato, R.L. (2016), La Guerra contra las Mujeres (Madrid, Traficantes de Sueños).

Serafini, P. (2018), 'Mediating Identities: Community Arts, Media, and Collective Identity in the Frontline Resistance to Fracking', Journal of Cultural Analysis and Social Change, 3(2): 11. https://doi.org/10.20897/jcasc/3992

Serafini, P. (2019), 'Community Radio as a Space of Care: An Ecofeminist Perspective on Media Production in Environmental Conflicts', International Journal of Communication, 13: 1-18.

Serafini, P. (2020), 'Cultural Production beyond Extraction? A First Approach to Extractivism and the Cultural and Creative Industries in Argentina', in K. Oakley \& M. Banks (eds), Cultural Industries and the Environmental Crisis: New Approaches for Policy (Cham, Springer), 51-64. https://doi.org/10.1007/978-3-030-49384-4_5

Sitrin, M. (2010), 'Horizontalidad, autogestión y protagonismo en Argentina', Historia Actual Online, 21: $133-42$.

Sitrin, M. \& Colectiva Sembrar (2020), Pandemic Solidarity: Mutual Aid during the COVID-19 Crisis (London, Pluto). https://doi.org/10.2307/j.ctv12sdx5v

Soltan, M. et al. (2020), 'To what extent are social determinants of health, including household overcrowding, air pollution and housing quality deprivation, modulators of presentation, ITU admission and outcomes among patients with SARS-COV-2 infection in an urban catchment area in Birmingham, United Kingdom?', BMC Public Health (preprint).

https://doi.org/10.21203/rs.3.rs-35617/v1 
Sultana, F. (2021), 'Climate change, COVID-19, and the co-production of injustices: a feminist reading of overlapping crises', Social \& Cultural Geography, 22(4): 447-60. https://doi.org/10.1080/14649365.2021.1910994

Svampa, M. (2012), 'Consenso de los commodities, giro ecoterritorial y pensamiento crítico en América Latina', Revista del Observatorio Social de América Latina, 32: Movimientos socioambientales en América Latina, 15-38.

Svampa, M. \& Viale, E. (2014), Maldesarrollo: La Argentina del extractivismo y el despojo (Buenos Aires, Katz). https://doi.org/10.2307/j.ctvm7bcs8

Télam (2020), El acuerdo con China para producir carne de cerdo prevé inversión de US\$3.800 millones. https://www.telam.com.ar/notas/202008/498399-el-acuerdo-con-china-para-producir-carne-de-cerdopreve-inversion-de-us-3800-millones.html

The Care Collective (2020) 'COVID-19 pandemic: A Crisis of Care', Verso Blog. https://www.versobooks.com/blogs/4617-COVID-19-pandemic-a-crisis-of-care

Trentini, F. \& Pérez, A. (2015), 'Formas de violencia hacia el pueblo mapuche en Argentina: Reflexiones a partir del caso de la comunidad Roberto Maliqueo', Argumentos, 28(78): 139-59.

Turcotte, H.M. (2011), 'Contextualizing Petro-Sexual Politics', Alternatives: Global, Local, Political, 36(3): 200-220. https://doi.org/10.1177/0304375411418597

Tronto, J.C. (1995), 'Care as a Basis for Radical Political Judgments', Hypatia, 10(2): 141-149. https://doi.org/10.1111/j.1527-2001.1995.tb01376.x

Ulloa, A. (2015), 'Environment and Development. Reflections from Latin America', in T. Perreault, G. Bridge \& J. McCarthy (eds), The Routledge Handbook of Political Ecology (London \& New York, Routledge), 320-331.

United Nations Human Rights Council (2019), Global extractivism and racial equality. Report of the Special Rapporteur on contemporary forms of racism, racial discrimination, xenophobia and related intolerance (A/HRC/41/54). https://undocs.org/A/HRC/41/54

Vásquez Duplat, A. M. (ed) (2017), Extractivismo urbano. Debates para una construcción colectiva de las ciudades (Buenos Aires, Fundación Rosa Luxemburgo; Ceapi; El Colectivo).

Watts, M. (1999), 'Petro-Violence: Some Thoughts on Community, Extraction, and Political Ecology', Berkeley Workshop on Environmental Politics (UC Berkeley). https://escholarship.org/uc/item/7zh116zd

Zibechi, R. (2012), Territories in Resistance: A Cartography of Latin American Social Movements, translated by Ramor Ryan (Oakland, AK Press).

To cite the article: Paula Serafini (2021), 'Extractivist violence and the COVID-19 conjuncture', Journal of the British Academy, 9(s5): 95-116.

DOI https://doi.org/10.5871/jba/009s5.095

Journal of the British Academy (ISSN 2052-7217) is published by

The British Academy, 10-11 Carlton House Terrace, London, SW1Y 5AH

www.thebritishacademy.ac.uk 